\title{
IDENTIFYING AND ANALYSING UNDERLYING PROBLEMS OF SHIPBUILDING INDUSTRIES IN BANGLADESH
}

\author{
K. Shahriar Iqbal*, N. M. Golam Zakaria and Kh. Akhter Hossain \\ Department of Naval Architecture and Marine Engineering, \\ Bangladesh University of Engineering and Technology, Dhaka-100, Bangladesh \\ *Corresponding email: iqbal.shahriar@gmail.com
}

\begin{abstract}
Shipbuilding is considered to be a thrust sector in the economy of Bangladesh. But various problems are there to obstruct the development of this sector. This paper is aimed to identify the underlying problems and then analyze the nature of the problems to make it helpful overcoming the obstacles. A brief history and prospect of the shipbuilding industries in Bangladesh in the perspective of global scenario is also discussed.
\end{abstract}

Key Words: Problem identification, shipbuilding industry, Shipyards.

\section{INTRODUCTION}

Bangladesh is a maritime nation with $1,66,000$ sq. $\mathrm{km}$ area of sea, abundance with living and nonliving resources ${ }^{1}$. There are more than 200 rivers all around the country, with a total length of about $22,155 \mathrm{~km}$, which occupy about $11 \%$ of total area of the country. Here rivers and water transports play a vital role for economical and commercial activities in Bangladesh. Major export and import of Bangladesh (about $85 \%$ ) is also traveled by sea ${ }^{2}$. At present more than 5,000 inland/coastal ships have been plying all over the country, which carry more than $90 \%$ of total oil product, $70 \%$ of cargo and $35 \%$ of passengers. More than 1,00,000 skilled workers and 150,000 semi-skilled workers are employed in this laborintensive industry ${ }^{3}$. All inland ships are constructed and repaired in local shipyards. Bangladesh harbours the second largest ship breaking industries in the world. They are the prime source of raw material including plate, frame, stiffener, longitudinal, pipe, old engine/generator, and even auxiliary machinery, for most of the local private shipbuilding yards. Those are used as raw material in manufacturing and repairing inland shipping fleet.

\section{A BRIEF HISTORY OF SHIPBUILDING INDUSTRY IN BANGLADESH}

There are hundreds shipyards and workshops in Bangladesh of which 124 have been reported to be registered with the Department of Shipping ${ }^{4}$. Out of these shipyards, approximately $70 \%$ are located in and around Dhaka and Narayangong along the side of the river bank of Buriganga, Shitalakha and Meghna. About 20\% shipyards of Chittagong division are located along the side of Karnapuli river and 6\% are located along the bank of Poshur river of Khulna division and remaining $4 \%$ are located in Barishal division ${ }^{3}$. Almost all inland/coastal/bay crossing ships are constructed and repaired locally in these local shipyards.

Private indigenous Bangladeshi shipyards are mainly constructing steel ships that are suitable for inland and coastal water. They can design and fabricate ship up to 3500 DWT to fulfill the demand of local market. The medium and small private inland shipyards are operating under individual management, with minor supervision of government

$\begin{array}{ll}\text { Nomenclature } & \\ \text { BIWTA } & \text { Bangladesh Inland Water Transportation Authority } \\ \text { BIWTC } & \text { Bangladesh Inland Water Transportation Corporation } \\ \text { CGT } & \text { Compensated Gross Tonnage } \\ \text { CPA } & \text { Chittagong Port Authority } \\ \text { DOS } & \text { Department of Shipping } \\ \text { DWT } & \text { Deadweight of Ship in Tonnes } \\ \text { EPIDC } & \text { East Pakistan Industrial Development Corporation } \\ \text { GT } & \text { Gross Tonnage } \\ \text { MPA } & \text { Mongla Port Authority }\end{array}$

J oumal of Mechanical Engineening, Vol. ME 41, No. 2, December 2010 Transaction of the Mech. Eng. Div., The Institution of Eng ineers, Bangla desh 
All inland and coastal ships are built by local shipyards and numbers of vessels built per year are quite many. They employ huge number of skilled and unskilled labours. Most of the private shipyards use plate, engine, component and machinery of old merchant ship collected from many ship recycling industries located in Bangladesh $^{5}$. But frequent accident and heavy human causalities of inland vessels often raise question about the quality of ships produced in local shipyards.

Private shipyards are the cheapest and real indigenous shipbuilding and repairing industries in Bangladesh. These industries need special attention by government to develop them as quality shipyards. However, among these yards, there are dozens who are capable of manufacturing good quality small and medium ships to fulfill the requirement of local ship buyers/owners. At present there are a few private shipyards where international standards are maintained. These shipyards are receiving order to manufacture world-class ships for international market. Of them, Ananda Shipyard and Slipways Ltd, Dhaka and Western Marine Shipyard, Chittagong have attained the capability to manufacture the ships of 10,000 DWT. Highspeed Shipbuilding \& Engineering Co Ltd is a joint venture with Mitsui Engineering and Shipbuilding Industry of Japan and it has also signed a deal for construction of ten small new ships for Japan, which cost US\$ 50 million.

After the independence of Bangladesh, the only significant development in public sector was the Chittagong Dry Dock Limited (CDDL). But, the other state owned shipyards like Dockyard and Engineering Works (DEW) and Khulna Shipyard Ltd (KSY) have failed to keep their reputation and subsequently have become losing enterprises. There were many reasons behind their losses. Among those reasons, the most known one was Balancing Modernizing Rehabilitation and Expansion (BMRE), which was not accommodated since couple of era due to lack of capital. CDDL, a public shipyard, showed good prospect of future as it has comparatively modern and equipped with effective machinery and facilities like merchant ship docked capability ${ }^{6}$.

Bangladesh has ample scopes to attract huge local and foreign investments in the prospective shipbuilding industry and can also earn substantial amount of foreign exchange by building new vessels for the world market. The CDDL, a subsidiary of Bangladesh Steel and Engineering Corporation (BSEC) under the Ministry of Industry, has long been engaged in ship repairing and serving in the country's fleet. A separate dock fully equipped with supplementary facilities can be set up here for the purpose of new shipbuilding. Two foreign countries also showed their keen interest in either to relocate their shipbuilding industries to Bangladesh or place orders to the CDDL for building new vessels for them.

Khulna Shipyard (KSY) Ltd is about 45 years old public shipyard. Till 1984 when Bangladesh Navy took over the shipyard, it remained as a sick industry and there was no sign of profit. But later on it has become a profitable industry. Vessels like gun boat, cargo vessels, floating cranes, water barge, water boat, tug, oil tanker, pontoon, LCT, trawlers, launch etc, have so far been constructed /repaired / renovated in KSY with good reputation. Its versatile dock facilities can accommodate a good number of ships at a time for repair or new building. The excellent assembly and outfitting area ensure a good working environment for high quality construction maintaining schedules. These shipbuilding areas have ample space and equipment for the simultaneous outfitting of sixteen medium size vessels. The construction works of KSY started in 1954 under supervision of the East Pakistan Industrial Development Corporation (EPIDC) with the technical support of West Germany. After completion of works, production started on 27 Nov 1957. A British firm was appointed as consultant. Later another firm from Switzerland was appointed for the same job. In 1957 Khulna Shipyard started construction of tugs, workboats and other commercial craft with standard design. Since then Khulna Shipyard has built (about 350), renovated and repaired more than 2300 vessels. Khulna Shipyard is currently committed to the design and build a wide range of new tugs, workboats and other specialized and cargo vessels up to 5000 DWT. The period 1973-84 can be termed as golden period for the shipyard where it suffered no loss and the highest amount of profit was earn in the fiscal year of 197677.

Dockyard and Engineering Work (DEW) Ltd is providing services to new shipbuilding and repair sectors in this region since its establishment in 1926. The organization was taken over by the government of the then Pakistan from the Royal Indian Marine Service after the partition of India. In 1954, the EPIDC took it over and transformed it into a public limited company. Subsequently, in this process it has come out with the capability of building and repairing vessels of all types up to 3000 DWT. It has further modernized in 1989 by introducing good machinery and sectionalized shipbuilding technology. This development was achieved to enable the yard to undertake construction of Ro-Ro ferries under a Danish aided project for BIWTC. But DEW was failed to keep its reputation and earning good profit later on. After declaring sick industry in 2002 it has stopped its activity and finally handed over to Bangladesh Navy in Dec 2006. Presently it is run by Bangladesh Navy and going to refurbish very soon with suitable BMRE. DEW has well shipbuilding capability to build quality ship for foreign buyer/owner. 
There are 69 private shipbuilding and repairing yards at various locations of Bangladesh that are manufacturing and repairing almost all the inland and coastal water transports. Among these, some have long shipbuilding history and reputation. Some private shipyard has attained international standard. They are manufacturing small and medium sized new ships for international market. Recently few of these shipyards have attained the capability to manufacture ships of 10,000 DWT. Very recently few of these private shipyards have received orders from ship owners of Germany, Japan, Denmark, Netherlands, EC, Mozambique, etc. Dozens of new ships already handed over to foreign owners. However, while the inland shipbuilding was at its nascent stage, Bangladesh got its first exposure to international ship building market in 1979. Japanese ship building giant, Mitsui Engineering and ship building industry developed the first and the largest joint venture shipyard with Highspeed Shipyard, Narayanganj. For the first time, Highspeed Shipyard, with their Japanese partners, was able to build vessels according to international classification society for meeting national requirement. This shipyard constructed five deep-sea fishing trawlers for local owner and received order by participating in an international tender floated by the FAO (Food and Agricultural Organization of UN) to build eight grain carriers. It built the first barge-mounted power plant for Rural Power Company Ltd (RPCL), several oil tankers, and fast moving patrol boat for Navy and troops carrier for the Bangladesh Army. Ananada Shipyard and Slipways Ltd. and Western Marine Shipyard Ltd. have sign contract over US\$ 600 million worth orders to make more than 40 vessels, with a capacity below 10,000 $\mathrm{DWT}^{3}$. As world ship owners are slowly but surely entering into Bangladesh with this prospect, it is expected that more local shipyards will improve their capability and quality very soon.

\section{BANGLADESHI SHIPYARDS IN WORLD SHIPBUILDING SCENERIO}

South Korea, China and Japan have been leading the world shipbuilding for the past few decades. The total world production share by some shipbuilding nations in 2008 is shown in Figure 1. According to the amounts shown in the figure, South Korea was leading the market having a lion share. But a change was visible in the following years. Figure 2 and Figure 3 shows the new shipbuilding contract signed by these nations in 2008. The figures show that South Korea was loosing there share where China and Japan were getting there share increased.

Presently market leaders of world shipbuilding industry are not interested to build small ships of less than 25,000 DWT and that market is open to the other shipbuilding nations. The current average increasing rate of ships in tonnage is approximately 21 million GT per year. Considering US\$ 7,620 construction cost per GT, total global market size is US\$ 1,600 billion. If Bangladesh can grab $1 \%$ of the global order of small ships market only (which is about US\$ 400 billion), the amount will be worth US\$ 4 billion $^{9}$. Again traditional market leaders of world shipbuilding industry are over-booked mainly for construction of large ships, so the ships' buyers/entrepreneurs are in search of incisive new, suitable and reliable markets in Vietnam, Bangladesh, India, Brazil, Indonesia, etc. On the other hand, the market of small-ships and vessels of various types is remaining unaffected by the recent global recession. Recession has caused a drop in demand for large vessels. Global giant shipbuilders cannot capitalize on this new market demand, as their projects will prove to be unfeasible because of the high overhead costs they already bearded. Moreover, orders for small ships have gone up because of the global financial crisis. Again shipbuilding history has seen that, in the recession, South Korea expanded its capacity instead of reducing business scales like Japan.

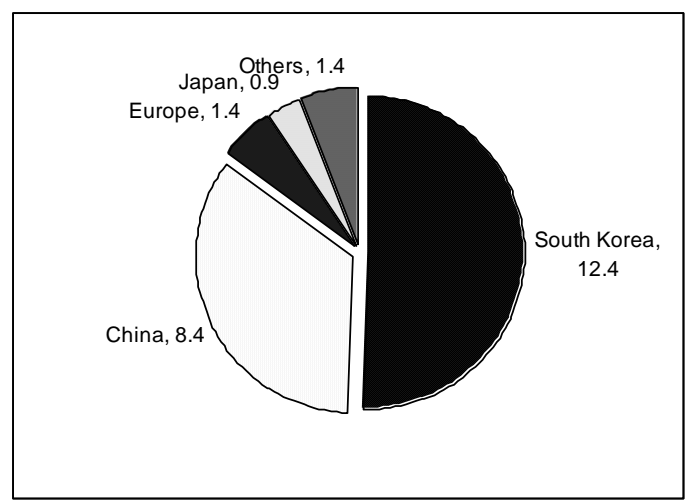

Figure 1. World Shipbuilding Production by Nations in year 2008 (in million GT) ${ }^{7}$

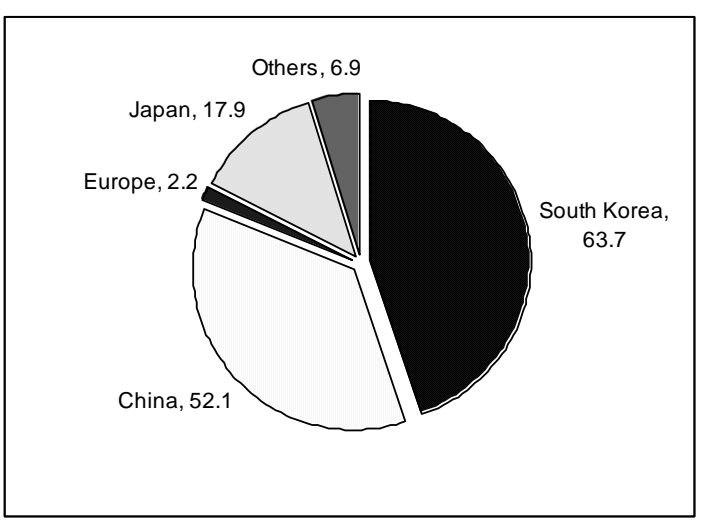

Figure 2. Global New Shipbuilding Contract by Countries in million DWT in $2008^{8}$ 


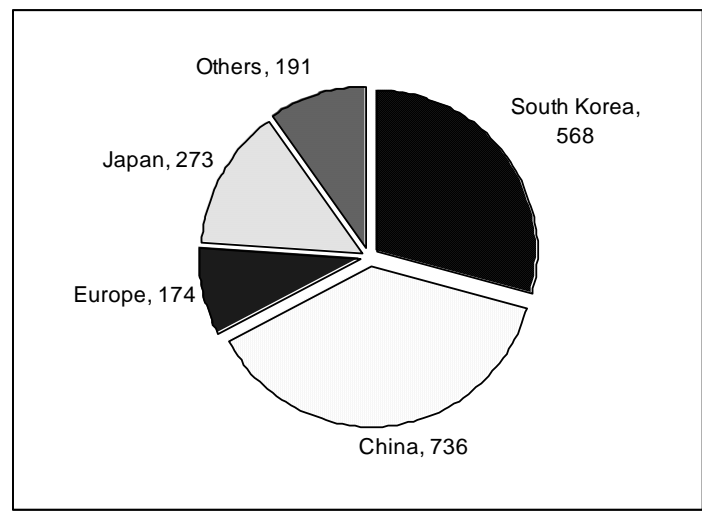

Figure 3. Global New Shipbuilding Contract by Countries in number of vessels in $2008^{8}$

Table 1 shows year-wise contract for number of vessels in world shipbuilding market and the share received by some major shipbuilding countries and Bangladesh during 1989 through 2008. The table shows how China and Korea takeover Japan after 2004. Bangladesh got a jump in receiving orders in 2007 and got a little slack afterwards due to the world recession.

Table 1. Shipbuilding contracts received by some major shipbuilding nations and Bangladesh ${ }^{10}$

\begin{tabular}{|c|c|c|c|c|c|}
\hline Year & $\begin{array}{c}\text { World } \\
\text { Total } \\
\text { (vessel } \\
\text { number) }\end{array}$ & $\begin{array}{c}\text { China } \\
(\%)\end{array}$ & $\begin{array}{c}\text { Japan } \\
(\%)\end{array}$ & $\begin{array}{c}\text { Korea } \\
(\%)\end{array}$ & $\begin{array}{c}\text { Bangla } \\
\text { desh } \\
(\%)\end{array}$ \\
\hline 1989 & 1050 & 2.86 & 42.86 & 11.43 & 0.00 \\
\hline 1990 & 1100 & 6.82 & 40.91 & 9.09 & 0.00 \\
\hline 1991 & 990 & 7.58 & 35.35 & 11.11 & 0.00 \\
\hline 1992 & 900 & 11.11 & 27.78 & 6.67 & 0.11 \\
\hline 1993 & 1000 & 9.00 & 37.00 & 10.00 & 0.00 \\
\hline 1994 & 2000 & 8.75 & 35.00 & 12.50 & 0.00 \\
\hline 1995 & 1950 & 9.23 & 30.77 & 12.82 & 0.00 \\
\hline 1996 & 1950 & 9.49 & 33.33 & 10.26 & 0.26 \\
\hline 1997 & 2100 & 9.52 & 30.95 & 11.90 & 0.05 \\
\hline 1998 & 1900 & 7.89 & 25.26 & 10.53 & 0.00 \\
\hline 1999 & 1500 & 11.33 & 20.00 & 16.67 & 0.00 \\
\hline 2000 & 1950 & 10.26 & 23.59 & 17.95 & 0.00 \\
\hline 2001 & 2500 & 16.00 & 20.80 & 9.20 & 0.08 \\
\hline 2002 & 2250 & 11.11 & 22.22 & 10.00 & 0.00 \\
\hline 2003 & 3100 & 16.29 & 22.58 & 16.45 & 0.10 \\
\hline 2004 & 3900 & 20.26 & 21.79 & 13.08 & 0.10 \\
\hline 2005 & 3850 & 20.78 & 13.25 & 12.73 & 0.03 \\
\hline 2006 & 5050 & 29.70 & 14.85 & 14.85 & 0.08 \\
\hline 2007 & 6600 & 33.33 & 11.21 & 19.70 & 0.35 \\
\hline 2008 & 3000 & 30.00 & 16.50 & 13.33 & 0.57 \\
\hline$V$ & $196 e n t y$ & $f e W$ & & & \\
\hline
\end{tabular}

Very recently few Bangladeshi shipyards have received orders from the foreign ships' buyers. Ananda Shipyard exported her first ship to a Danish company on May 2008. And with this great event, Bangladesh has successfully exported her first ocean going ship to a high end market like Denmark competing with giant competitor like Chinese and Vietnamese ship builders. In December 2008 Ananda Shipyard exported six classed ferries and boats including three aluminum catamaran passenger vessels, securing orders through international tender under World Bank. Ananda Shipyard has also signed contract with Germany, Denmark and Mozambique to build more than a dozen ships with the value of
US\$ 300 million $^{11}$. On the other hand, few more quality shipyards like, Western Marine and HighSpeed have also received orders to build dozens of ships from Germany, Netherlands, Japan, Denmark and Finland costing approximately US\$ 300. There is a strong opportunity to attract considerable foreign investment on shipbuilding by way of utilizing skilled and low wage workers. As world ship owners are slowly but surely entering into Bangladesh with this prospect, it is expected that more qualitative shipyards will be surfaced in Bangladesh.

\section{UNDERLYING PROBLEMS OF SHIPBUILDING IN BANGLADESH Problem Identification}

To identify the problems underlying the shipbuilding in Bangladesh, extensive surveys and field visits were carried out in different shipyards in Bangladesh. Consultations and meetings with government authorities, shipbuilding associations, existing and upcoming shipyard personnel and its related stakeholders were made to get a picture about the challenges they were facing in performing there works. Private and public shipyards around the country were visited to collect primary data ${ }^{12}$ and information about the local shipbuilding practice was collected through interacting with structured, unstructured and open ended questionnaires. Shipbuilding process (such as ship design, steel treatment, plate and section preparation, welding quality, steel work, fabrication, outfitting work, hull erection and launching) was observed to find out the difficulties involved in it. Primary and secondary data about labor, labor hour and labor cost were collected to evaluate the standard of local shipyards and to compare them with other shipbuilding nations. Professional participations were conducted through questionnaire and interviews. The organizational set up, working environment, management practices, performance and future vision of local shipyards were also compared with other shipbuilding nations.

\section{General Problems in Bangladeshi Shipbuilding}

In the past, shipbuilding industry of Bangladesh failed to keep pace with consistency due to lack of proper government and private initiatives as well as anti-industry mindset of the nation. This has ultimately caused non-penetration in international business as a shipbuilding nation. In future, some issues like safety, efficiency and environmental concerns will turn this sector into a more innovative one, which may enable the new generation to face the challenges to resolve the problems arising out of it. Countries with large population like Bangladesh may feel encouraged to come forward in labour intensive shipbuilding sector due to their abundant manpower. Currently the world is passing through economic recession. Shipping and shipbuilding of the world are affected from this recession resulting 
cancellation of new building orders at least for the time being. The present shipbuilding sector in Bangladesh is not that big industry and only a few shipyards are involved in exporting ships, but revenue generated from this sector is promising. In spite of enormous possibilities of expanding shipbuilding industry in Bangladesh there are also some problems. These existing problems of this sector may be categorized ${ }^{13}$ in the following broad headings:

a. Financial problem

b. Human Resource Development problem

c. Infrastructure problem

d. Marketing problem

e. Management problem

f. Technical problem

g. Quality control problem

h. Delay delivery problem

i. Pricing problem

j. Safety, health, and environmental aspect

k. Economic recession and its effect on Bangladeshi shipbuilding

l. Some special problems

\section{Financial problem}

Shipbuilding is capital and labour intensive industry. The local commercial banks are not individually capable of making required investment in this industry. Besides, consortium financing is time consuming and a complex process, which is not so favorable for making investment in this sector. There is no standard framework for forming consortium and as a result when a shipbuilding contract is obtained, the time lag of securing finance by forming consortium kills the contract. There is dearth of capital and investment especially when the scale of investment is to the tune of 100 to 1000 crore or more because of the risk is considered too high for both the entrepreneurs and bankers. As a results, productivity expansion and export promotion are being impeded.

High rate of interest is applied on industrial and working capital loan. Existing rate of interest, ranging from $12 \%$ to $16 \%$ for industrial and working capital loans, is not suitable for the development of this sector. Whereas $7 \%$ rate of interest on export credit is prevailing for other export sectors like ready made garment sector.

As the buyers do not accept the guarantee provided by the Bangladeshi commercial banks, counter guarantee has to be given from the foreign banks. As a result, guarantee from both local and foreign banks is mandatory for export of ships from Bangladesh. The prevailing cost of bank guarantee due to double bank guarantee system has become a real burden for local shipyards. Bank guarantee for export of ships from Bangladesh is about 16\% (local $4 \%$ and foreign $4 \%$ for two year period). Such bank guarantee requires equivalent amount of advance payment and price of raw materials received by the builders from the importing company. Bank guarantee commission for other sectors in Bangladesh is charged at the rate of $1 \%-2 \%$. On the other hand, it is $0 \%$ in other competing countries like Korea, China, Japan, India etc. Commission at the rate of $0.20 \%$ is charged by banks of other competing countries for opening import $\mathrm{L} / \mathrm{C}$ whereas $1 \%$ per quarter i.e. $1 \times 4 \% \times 2$ years $=8 \%$ is charged by the Bangladeshi commercial banks. The breakup of the cost incurred for payment of interest and service charges indicates that the additional financial cost of ships built in Bangladesh is about 15 to 25\% (bank interest 3 to $6 \%+$ guarantee 8 to $16 \%+\mathrm{L} / \mathrm{C}$ commission 4 to $8 \%$ + other charges 1\%) higher than the other competing nations like China, Korea, Japan, India, Vietnam, Brazil etc.

Because the industry is not understood properly by concerned policymaker, the usual response to such investment proposal is halfhearted and is treated in the same format as in case of other export sectors. Thus banking support that the shipbuilding sector enjoys according to the current policy is poor. More over Bangladeshi commercial banks are shy to deal with big investment individually as required for shipbuilding sector.

Insurance of a ship is taken on keel laying, the value then being nearly only $.001 \%$, which increases gradually over the building period to $100 \%$. In reality the full value is matured only on acceptance and closing of the financial deal to delivery of ship. The insurance premium should also be proportional to the value and should be adjusted at quarters. None is aware of this concept here. As a result, the insurance premium is becoming prohibiting and discouraging to a builder and thus making the project vulnerable to unforeseen risks.

\section{Technical problem}

There is insufficiency in the number of ancillary industries to support the shipbuilding industry as backward linkage by providing service and supplying ships' components. The local shipyards are having lack of research and development (R\&D), which ultimately fail to bring about any innovation and technological development for price competitiveness in international ship markets. At present Bangladesh is not working in the field of ship design, though skilled manpower is available. As a result, lack of adequate and expert design firms and expertise in design are an impediment for high value added product. More over, most of the local shipyards are lacking of modern shipbuilding tools, machineries and technology. At the same time lack of expert machine operators is found in the most local shipyards. Local shipyards owner consider every human resource development program as money drain, not gain. That's why they are maintaining poor training facilities of the technical personnel. Despite 
long heritage, Bangladesh has failed to keep pace with consistency with the continuous technological development of global shipbuilding industry.

Bangladesh does not produce inert gases. Therefore production with aluminum and other similar works suffer. Importation of inert gases is insufficient and schedule of import is planned for monopoly profiting. Non-availability of inert gases in local market put obstacles for these projects. Other required gases are also not easily available.

In a ship, there are about 4000 different components, which are to be installed within a very limited space of the ship. Unlike land installation, electrical fitting and installation are very delicate in ships and needs more precision. There is a lack of skilled manpower in Bangladesh in such specified field and particularly in electrical installation and fitting.

Lack of model testing and other facilities in Bangladesh also matter. The age of the Department of Naval Architecture and Marine Engineering in Bangladesh University of Engineering and Technology is 35 years. Towing tank was expected by the Department since its establishment. But the hope has never seen the light. NDT and Design Lab facilities are also poor in every institutions and shipyards around Bangladesh.

\section{Infrastructure problem}

Access to the rivers and sea, that is, foreshore for shipbuilding entrepreneur is restricted by bureaucracy problem like unfriendly attitude of the administration toward local shipbuilding. Impositions of foreshore charges, which are abnormally high as well as the charges on erected installations such as service jetty, etc. are also high and in some cases duplicate charges are imposed. The lack of electricity and gas supply is a major impediment which hinders the setting up of shipbuilding industries in Bangladesh. Existing ban on importation of rail and sheet pile imposed by railway authority also obstructs developing this industry. Under the present import policy and foreign currency regulation, import on CIF basis is not permissible. But this industry cannot run under such a rule. Shipbuilding industry needs a lot of components, parts and accessories leading to emergency import during the construction period. Existing facilities are not adequate for emergency import requirements ${ }^{14}$.

There should be a proper association of export oriented shipbuilding industries in the country to maintain mechanism for proper implementation, monitoring and updating strategy for ship export

Other than government owned dry-dock, none of the shipyards have the dry docking facilities. Most of the shipyards are located in and around Dhaka, far away from the sea. This is not a good approach to develop shipyards for building sea going vessels. The rivers and channels are frequently silted. It is very difficult to maintain channel for desired level of navigability for ships maneuver. The restricted draught (Maximum 4.0 to 4.5 Meters) is the limitation to the size of a ship that can be built in these shipyards. Bridges and overhead cables may induce new restriction to the ship size that may be built in a shipyards located in the hinterland.

There is no adequate backup industry to produce required standard of MS plate need for ship construction.

\section{Marketing problem}

Bankers, stakeholders, custom house, foreign affair departments, government monitoring and regulating bodies, etc are not fully aware of the local shipbuilding industry ${ }^{13}$. There is a lack of activities to promote Bangladesh as a shipbuilding nation. One of the bottlenecks in ship construction in Bangladesh is the current lacking of convenience for procurement of material, machineries and equipment. There are no organized manufacturing plants for manufacturing the components. Information on prospective overseas buyers is not made easily available. In $21^{\text {st }}$ century, all countries will be considered as global village due to the effect of globalization. Now good reputation is extremely required for export oriented shipyards to sustain in the international business arena. So buyer's interest should be given utmost importance. Unfortunately local shipyards fail to give due value to the foreign customers. Foreign ship's owners and their representatives have some reasonable complains about behavior and attitude of local shipyards. The image problem of the nation hinders the export of ships.

Europe has been found, till now, as the main market of export of ships from Bangladesh. Requirement of the safety and standard of work at the shipyards according to the European buyers are quite high. Hard head \& hand, protected eyes \& ears, safety shoes, safe working environment, adequate fire fitting appliances, providing fresh drinking water and comfort to workers during break time require to be maintained. But most of the local shipyards are not maintaining /practicing this standard.

Our state diplomacy is not strong enough to support export of ships. In difficult contractual commercial negotiation, it is a must to have adequate support from our mission abroad, our government as well as cooperation of foreign embassies in Bangladesh. It is observed that when a difference of opinion crops up, an embassy in Bangladesh takes the side of ships' buyers and influence the situation. On the other hand, under similar circumstances a Bangladeshi mission abroad does not take care of the Bangladeshi builders. Bangladesh shipbuilders have few such bitter experiences.

\section{Management problem}

Most of the local shipyards do not follow corporate management culture. Family members and friends occupy the important managerial appointment 
like director, executive committee member etc. of the local shipyards. Such family and friend management culture is one of the hindrances to the development of the industry and also will not commensurate with international arena ${ }^{15}$. Poor communication between upward and downward grid in the managerial chain exists. Middle management neither enjoys any financial authority nor decision-making process (with little exception in few shipyards). As a result, poor command and control as well as negligible dedication of the employees toward the organization observed $^{16}$. Most of the local shipyards practice one man show management culture. Every decision comes from owner as per his/her desire and wish. Many of the owners do not care about the welfare of the employees. So poor job satisfaction observed in most of the shipyards and employees do not feel belongingness to the organization. As a result huge absenteeism and turnover of labours and skilled manpower observed. Workforce never enjoys fringe benefit and other labour welfare activities like medical, pension, travel and daily allowance, accident and other compensation etc. Most of the labours are employed in casual basis ${ }^{17}$.

Every valued customer looks at the quality of management. How is the management performing? What are the managerial tools that are using by the yards to ensure continuous improvement of product? Are the managerial staffs responsible and capable enough to solve the day-to-day problems? Is the management prompt to solve the daily problem? But it is really discouraging that answers to those questions are negative for most of the local shipyards. The government policies are complicated and not very pleasant in supporting the expansions of the industry as a whole.

\section{Human resource development problem}

The number of available graduates, skilled supervisors, foreman, specialized welders, cutters, fitters, machine operators and other technical skilled manpower that are required for shipbuilding and allied industries are far less than the minimum requirement. Substantial number of skilled manpower leaves the country for overseas employment as there is inadequate number of shipyards in the country. The local shipyards lack of dedicated human resource department. Government also does not have long-term vision as well as accomplishing her mission for human resource development for the country. In fact, every thing is running in Bangladesh on ad-hoc basis.

\section{Quality control problem}

Lack of quality control groups and their work and capability are in question. A number of questions against them are raised by the foreign ship owners or by their representatives. But many of the local shipyard owners are failed to satisfy them. Shipyards must remember that quality accelerate entire process to get the next contract $^{18}$. Lack of sincerity of workers due to poor job satisfaction and working environment limits the opportunity of further development. The owners do not bother about working environment due to the availability of labour with lower cost.

Quality is the prime requirement of shipbuilding industry. A ship, which plies on the sea far away from the shore for quite a many days at a stress, must have to be flawless. Quality in a shipyards usually maintain by quality control group of shipyard itself, by the classification society and by the owners' representative. This is very demanding that everyone in the system must be cautious, dedicated as well as prepared to undergo strenuous activities. A chain of such professionals is necessary. But it is missing in local shipyards. It needs time to develop such quality assurance activities in local shipyards ${ }^{19}$.

Bangladesh is lacking in the safety culture. Safety is a long-term investment. Though the initial cost for safety assurance may be high, the gain in the long run is accumulative and it adds to the quality. Bangladesh has to be competitive with the other shipyards around the world. Government may sponsor benchmarking activities.

\section{Delay delivery problem}

As Bangladesh is a new player in exporting ships to foreign countries, it will take some reaction time. With the on going experience it will come with a good solution to many problems. But foreign ship owners are not reluctant in this matter. A timely delivery is a major factor of shipbuilding because of the involvement of huge capital. But punctuality is not habitual in our culture. Here hours pass in traffic jam, days pass away on moving files, and projects are delayed. In general Bangladeshi shipyards are often not able to match the delivery time of a new ship building with that of other countries. Most of the local shipyards do not follow the modern job evaluation and execution technique (such as PERT, CPM etc). They maintain poor management and planning process for entire system/job. As a result, liquidated damage due to delay delivery is foreseen. Renowned export oriented foreign shipyards deliver a ship in about six months, whereas local shipyards take 2 to 3 years to build and deliver similar ship

Shipbuilding is a complicated and heavy engineering process demanding high skilled planning, monitoring, quality control as well as accuracies in engineering works. Every ship is an individual project and requires specific planning, programming and scheduling. In time procurements, i,e., well drawn planning, opening of letter of credits, payments of advances, where necessary, must be flawless as all activities are interdependent. Banks and customs houses must understand and do the utmost for maintaining schedules. This is highly lacking in Bangladesh. There is severe deficiency of 
expertise in this area in Bangladesh. Ultimately delay becomes a must in delivery of ship.

Absence of adequate government care in new export orientated shipbuilding industry plays a vital role behind the delay. Proper green channel facilities by customs for $100 \%$ export oriented shipbuilding industry are absent. Clearance of importable goods through the custom in Bangladesh is one of the complicated and troublesome jobs. Because of checking, rechecking and examination by an expert committee, in some cases, more than six months are elapsed By that time imported goods got damaged or lost at the port. Green Channel system of clearance can solve the problem. Again spirit of Green Channel may be lost if some complicated conditions are enforced. As it happened in Bangladesh, where importing of raw materials through Green Channel needs to fulfill 13 different conditions and 6 different certificates need to be produced. In shipbuilding thousands of items are necessary to be imported. Due to the laps in early identification or for an item lost on the way or damaged during fitting or nonfunctioning equipment, emergency import of such item is necessary. For non-availability of few small items may delay the delivery of entire ship. So import of export-oriented ship's items should get special care and spirit of green channel should be maintained. Unfortunately, in many cases it is not maintained.

Loss of output and dissatisfaction of owner are colossal for delay delivery. Out of power supply is a common phenomenon, which often continues for quite sometime in Bangladesh, and one of the reasons for delay delivery. A shipyard's load consumption pattern is similar to the freight index wave. Use of shipyard's generator is not a solution.

\section{Pricing problem}

Indian shipbuilding industry are enjoying initial five-year (more than 30\%) government subsidy to develop them up to the mark of international standard. Most of the international export oriented shipyard is availing tax- holiday by their government. But it is not the case for Bangladeshi export oriented shipbuilding industry. Moreover high tax on imported shipbuilding machineries and components enhanced the ship price further to some extent

Lack of expert financial department and poor future forecasting in decision-making process in the local shipyards are also behind the cost escalation. Shipbuilding requires guarantees to be issued by banks acceptable to foreign buyers. But Bangladeshi commercial banks have to obtain counter guarantees from foreign banks. For issuing bank guarantee annual $8 \%$ commission is charged by local and foreign banks. This adds to the cost of capital. From the discussion with shipbuilders and banks it is visualized that bank interest and service charges are too high in this sector compared to that of other international competitors. This is one of the major obstacles to develop shipbuilding industry in Bangladesh.

Shipbuilding in Bangladesh suffers due to nonavailability of allied supporting industries such as that for manufacture and supply of control panel, switchgears, cables, electrical fittings, fire doors, windows, deck fittings, galley items etc. It is sorry to mention that, quality of galvanizing, as necessary for piping and fittings, is not up to the standard. Cost of building ships will reduce substantially when these allied industries grow in Bangladesh and retention will also then increase substantially.

The equipment manufacturers of foreign countries do not place good and competitive offers for Bangladeshi shipbuilders, which make the cost of imported items higher and so the construction of the total ship. Again components of $60-65 \%$ of the total contract value is to be imported from abroad for orders placed in Bangladesh ${ }^{20}$. In case the high share of the local manufacturer/supplier of components and services, both the schedule could be maintained and cost could be made less.

\section{Safety, health and environmental aspect}

Safety, health and environmental (SHE) aspects of using various shipbuilding materials in the shipyards including the affect of harmful substances and related exposure in movement of materials and also the required measures were identified. Only a few shipyards have been found to be conscious about safety, health and environmental aspects, which are again at average level. The shipbuilders are more engaged in enhancing their skill in technology, financing and marketing. Safety, health and environment are yet to be recognized as important issues in all spheres of the society. The long term effect of safety, health and environmental measures are yet to be understood. Proper awareness and training and govt. regulations are required for improvement of the SHE aspects.

The regulations are to be made in a way that the prospective shipbuilders do not take these as hindrance. These aspects should be shipbuilder friendly, specially, because Bangladesh has just started developing the export oriented shipbuilding industry. The foreign buyers have a major role in enhancing the level of SHE in the builders yard.

Currently, nothing allures more public attention than the environmental aspect. In the shipbuilding process, many working procedures are polluting if proper preventing measures are not in place. Among them, the process of shot blasting, plate and section preparation, welding and painting is the most significant troublemaker. In case of shot blasting in open air, the controlling and diminishing of waste, which is dust and sound, require expensive appliances. The costs to reduce pollution absolutely go to the accounts of the shipyards. Such additional expenses are unavoidable in developed countries. In 
shipyards paints are widely used. These paints contain volatile organic compound (VOC). VOC is an element that produces Ozone by responding to sunlight. Developed countries like countries in European Union limited the quantity of emission or disposal of contamination of this kind. It is possible to use the paints that contain no VOC, but the expenditure for painting of the ships will go high.

\section{Economic recession and effect on Bangladeshi shipbuilding}

In Bangladesh, among 69 small and medium dockyards and their associated organizations, only a few companies have been able to attract foreign buyers. Ananada Shipyard and Slipways Ltd and Western Marine Shipyard Ltd have received over US\$ 600 million worth orders to make more than 40 vessels, with a capacity below 10,000 dead weight tonnes (DWT). Most of the orders for these ships come from various European countries like Germany, Netherlands and Denmark. The recent worst global recession has caused funds to dry up, making it difficult for shipping lines to arrange loans for new vessels. In 2009 global orders for building vessels have come down to less than one-third of the total orders of about 10,000 ships in 2007. Bangladesh, a new entrant in global shipbuilding market, is yet to face any cancellation of orders or deferment in payments, like traditional shipbuilding nations. Local shipyards owners' view that, the year 2009 appeared to be gloomy and low profile year for shipbuilding worldwide, but it would not affect Bangladesh. Bangladesh was concerned but not worried because our market was quite different. Bangladeshi shipyards build project vessels, not large ones, orders of which were cancelled. So Bangladesh would not face any blow like cancellation of orders.

\section{Some special problems}

In the last three years government agencies like Ministry of Industry, Ministry of Finance, Ministry of Shipping, Bangladesh Bank, National board of Revenue and even Prime Minister's Secretariat have shown keen interest to support the export oriented shipbuilding. There had been three high power committee to conduct a study on the prospect of this field and they submitted their reports. But it is really unfortunate for the industry that there has neither been any policy paper nor any specific government support declared yet. As a result, ships' buyers are very skeptical about the smooth sailing of specific shipbuilding project. Because, buyers take risk through paying the advance and the hard resources. It is extremely important to make the position of the government clear regarding export oriented shipbuilding in writing. Government is also somehow reluctant to make necessary regulations in accordance with the guide lines of International Labour Organization (ILO) \& International Maritime Organization (IMO) and to convince the concerned organizations /institutions to ensure proper compliance to the issues related to the said organizations.

Shipbuilding is a foreshore dependent industry. It is possible to control the industry as environmental friendly and does not have high impact on spoiled water or flow of river. Foreshore is under the control of BIWTA. But it seems BIWTA, in some extent, hesitate to support shipbuilding industry. They usually impose unbearable charges for using foreshore by the shipyards.

Attempts are being seen to import vessels and craft which Bangladeshi shipyards can build on their own soil. As an example, recently the $2^{\text {nd }}$ hand patrol craft was imported by CPA. This type of vessels can easily be manufactured in Bangladesh.

Intricacies of various requirements of export oriented shipbuilding such as timely delivery, handling of owners' supplies, closing of a financial deal, timely action of bank and quick clearance of ship on acceptance etc are not appreciated in Bangladesh. Policy makers, officials, bankers, and potential government authorities are not adequately conversant and therefore not complacent to complexities of shipbuilding. These create the real bottlenecks for the nascent shipbuilding.

CIF basis import is not allowed due to some reasons. But CIF basis import is a necessity for export oriented business to reduce the risk of company. As an example, if a propulsion plant, which comprises of main engine, stern gear and propeller; is imported on CNF basis and insurance is covered by the importer (i.e., builder), for any damage of materials, importer will be compensated by insurance company. But the lost or damaged materials need to be imported again. So if an incident happens and, for example, propeller is lost, the propeller needs to be produced again by the manufacturer and to be imported in the same way. Ultimate result is the delay of entire shipbuilding by, in some cases, one year. So shipbuilder will face huge liquidated damage and will incur uncompensated loss. But in case of CIF basis import, the supplier or manufacturer had to supply the complete package in his own responsibility during any loss or damage of materials. So builder is in safe side in CIF basis import.

The social environment outside the shipyard area is also an important factor which affects the possibility of recruiting competent people who would have the chance of staying inside or in the vicinity of shipyard area with their family. The social environment comprises among other factors, schooling for children, modern markets, recreation clubs etc. Most of the local shipyards are located in remote area without having such social environment.

An owner's foreign representatives often need to stay for a year or more and pay occasional visits to the owner or to his family. So visa for a year with multiple entries without restriction on duration of 
stay on an entry is necessary for them. But the process is cumbersome, time consuming, costly and earned bad image for the nation.

\section{ASSESSING THE SHIPBUILDING PROSPECT OF BANGLADESH}

There had been a boom in shipbuilding industry across the world up to 2007. Demand for new orders had spiraled because of following reasons:

- $\quad$ New Regulations imposed by IMO made it almost impossible to have the older ships upgraded and thus had to be replaced by new ships.

- $\quad$ Increasing price of fuel had made shipping business extremely competitive and older energy inefficient ships were found obsolete.

- Globalization led to increase the international shipping trade between the East and West several folds. The expansion of European Union also helped the market to be expanded further.

- $\quad$ Countries become global villages. Now any industry or investors can continue his business anywhere and anytime in the entire world. Goods will be manufactured in one side of the world and sold to consumers on the other side. So, the world turnover and activities have been increased manifold in the last few years. As a result, demands of ship and shipbuilding activities have been increased.

By depending on unique nature, convenient geographical advantage together with availability of less expensive technical personnel, abundant of skilled and semi-skilled workforce and long past heritage, the shipbuilding industry of Bangladesh has started its journey towards export. This industry is manufacturing cargo vessel, passenger craft, combine carrier, Ro-Ro ferries, tug, fishing trawlers and tankers etc. for inland and coastal routes catering to the local demand. Bangladesh has also successfully exported few ocean-going ships to foreign countries.

Bangladesh is known as ship breaking country, because approximately $40-50 \%$ of worlds scraped ships are being processed in Bhatiary and Shitakund at Chittagong coast of Bay of Bangle. But due to the revolutionary trend in the world shipbuilding sectors, the prospect of Bangladeshi shipbuilding has also come into discussion. Being a maritime country, Bangladesh has got many rivers and channels connected with sea. On the other hand, the people of this area have the pride on shipbuilding industry since the early stage of its civilizations. So the country has got good potential in respect of rising trend of shipbuilding industry.

Interviews of shipyard owners, ship builders, foreign buyers, stake holders and related personnel were conducted to gather their ideas on Bangladeshi shipbuilding industries. These were then evaluated to find the prospect of Bangladeshi shipbuilding. Chairman of Ananda Shipyard and Slipways Ltd viewed ship building as the second largest exporter after garments in 2015. Managing Director of Western Marine Shipyard Ltd was optimistic that Bangladesh would be able to grab one per cent of the global order for small ships in coming years and it will fetch $\$ 4.0$ billion for Bangladeshi shipbuilding industries. One of the former heads of Naval Architecture and Marine Engineering Department of BUET stated 2007-08 was an epoch-making year for the country's shipbuilding industry. Shipbuilding experts expressed that the country had become a new destination for companies seeking construction of small ocean-going vessels because the traditional shipbuilding nations like South Korea and China focused on building large ships. Even Vietnam, which is relatively new in shipbuilding, is no longer interested to build small ships below 25,000 DWT. They want to build bigger vessels because it is relatively cheaper and requires less labour per DWT. Their unwillingness has made India, Bangladesh, Indonesia, Pakistan, Myanmar, Thailand, Brazil etc the new destinations for small shipbuilding.

Shipbuilding experts acknowledge, it is only a matter of time that Bangladesh emerges as a major hub for building small ocean-going ships. Classification society, Germanischer Lloyd (GL), confirmed that Bangladesh always had enough skilled and cheap workforces. Now the nation needs know-how and facilities. They also foresee the local shipbuilding as a billion-dollar industry in next five years and it can easily be a global leader in the smallship building industry. Germanischer Lloyd has prompted Ananda Shipyard and Slipways Ltd and Western Marine Shipyard Ltd to look for international order. At GL's insistence, four more shipyards, High-speed Shipyard at Narayanganj, Karnaphuli Shipyard at Chittagong, KSY at Khulna and DEW at Narayanganj, have started upgrading their infrastructure to build seafaring ships. These four companies have ready-made manpower and the skill to build ships. They built hundreds of passenger ferries (locally called launches), coasters and tankers for local market. With some technological help and upgraded infrastructure, they will soon be able to build ocean going ships. Shipyard owners hope that the industry even has the potential to supersede the country's garments sector, the highest export earner, in the long run. The success of these local shipyards has encouraged other local companies such as Meghna Group of Industries, Rangs Group, Khan Brothers etc to jump on the bandwagon of global shipbuilding market. It took us 25 years to earn US\$ 10 billion a year in the garments sector. The Bangladeshi shipbuilding can do it in less than 10 years. The European Commission (EC) has shown keen interest to provide support to the shipbuilding companies in Bangladesh to gain a strong foothold in global shipbuilding market. The head of the 
delegation of European Commission (EC) in Bangladesh (on June 1, 2008) stated that Bangladeshi shipbuilding industry had all potential to earn billions and to bring benefits both to the people of Bangladesh and the European Union. It is particularly appropriated that a country, which has become renowned for ship-breaking, should move into shipbuilding, creating an industrial 'cycle of life' with a certain poetic appeal.

\section{CONCLUSIONS}

In spite of having very promising opportunity, in the past shipbuilding industry of Bangladesh failed to keep pace with consistency due to lack of proper government and private initiatives and this had ultimately caused non-penetration in international business as a shipbuilding nation. Even the water transport sector of this country had been receiving very low importance from the government since the independence of Bangladesh. Figure 6 shows how the allocation for water transport sector had been diminishing in course of time ${ }^{21}$.

Government Allocation in Annual Development Programme for Different Mode of Transport

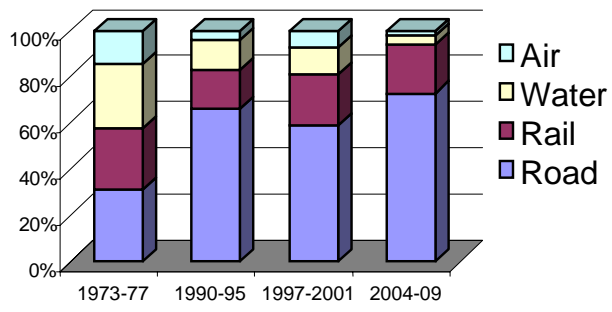

Figure 4. Government allocation in Annual Development Program for different mode of transports since independence of Bangladesh

Use of mostly import -based raw materials in the shipyards, drainage of skilled manpower, inadequate financial support, reluctant to maintain reliability and reputation in the international market, absence of backward linkage industries, crisis in the energy supply, failure to maintain schedule for delivery, absence of proper management and planning, complicated government policies are identified among the problems that obstruct flourishing shipbuilding industries in Bangladesh. Only few shipyards have been found to be conscious about safety, health and environmental (SHE) aspects, which are again at average level. The cost required for these measures should be considered as investment and not as expenditures.
For construction of vessels under local regulations, very few new components are used. On the other hand, in case of class vessels, almost all the components used are new and imported from abroad. European ship buyers/owners, who are the valued customers for Bangladesh, put the condition that components of $60-65 \%$ of the total contract value are to be imported from abroad. So both the schedule and cost are made expensive.

Inadequate number of skilled and loyal workforce is a major shortcoming for the rapidly growing industry. Government in conjunction with shipyard owners should endeavor to formulate a welfare policy for yard workers and professionals so that more people get attracted to these professions and the rate of staff turnover remains very low.

Bangladesh government should allow at least few more shipyards to be established along the river Karnaphuli or sea shore at Chittagong port area. Then many international companies might be willing to set up joint venture shipyards so that medium to larger vessels could be built here and exported.

Despite the low cost of labour, Bangladeshi shipyards have to bear more than $15-25 \%$ additional financial cost in various forms such as bank interest, bank guarantee, LC commission etc. Due to the current economic recession, some of the big giants involved in shipbuilding are losing their capability, which can ultimately bring good opportunity for those countries that can manufacture ships at a competitive price. From this point of view, it might be an opportunity for Bangladesh provided the aforesaid $15-25 \%$ additional financial cost is reduced substantially. It is the government who has to take initiative guiding and motivating the financial institutions to reduce present interest rate, commission and other charges.

Even though several problems are involved, with the convenient geographical advantage together with availability of less expensive technical personnel, abundance of skilled and semi-skilled workforce and long past heritage, Bangladesh has a very good opportunity to become a shipbuilding nation by $2016^{22}$.

Bangladesh is a developing country. Each and every citizen of this country expects the overall development of the country. But in most of the cases it is not materialized in reality. In the past, we failed several times to take the advantages and lucrative opportunities of modern trade and commerce due to the delay in our response. For this reason, our overall economic development has undoubtedly been interrupted time and again. So the concerned authorities have to be watchful and careful to take the opportunity to push the shipbuilding sector ahead as a thrust sector through fixing the identified problems leaving no delay. 


\section{REFERENCES}

[1] Alam, Com.M.K., 2004, "Bangladesh Maritime Challenges in the 21st Century”, Pathak Shamabesh Publication, Dhaka, pp. 21.

[2] Chittagong Port Authority, 2007, Year Book of the Chittagong Port Authority.

[3] Hossain, K. A. and Zakaria, N. M. G., 2008, "Potentiality and Prospect of Shipbuilding Industries in Bangladesh”, Journal of NOAMI, Vol.25, No.2, pp. 33-54.

[4] Department of Shipping, 2009, Shipyard Statistics, Engineering Section.

[5] Tabarak, U.A.Z.M. and Rahman, A.A, 1999, "Background Paper on Ship BreakYard”, Dhaka.

[6] Brochure of Chittagong Dry Dock Ltd, Overview, www.cddl.gov.com

[7] Shipbuilding Global Orderbook in million GT Wikipedia, www.wikipedia.com

[8] Different Statistics \& Charts related with Ship and Shipbuilding business, www.clarksons.net/ts/charts

[9] Hossain, M. S., 2008, Western Marine Shipyard Limited, Bangladesh set to emerge as new shipbuilding hub, Financial Express, February 5.

[10] Patrik, W., 2008, Regional Sales Director, Ship Power, Wärtsilä Corp. Lecture in Seminar in Dhaka at Hotel Radisson on Oct 11.

[11] Brochure of Ananda Shipyard and Slipways Ltd, 2009.

[12] Churchill, G. A., 1995, "Marketing Research Methodological Foundation”, Sixth edition, Harcourt Brace College Publishers.

[13] Hossain, K. A., 2010, "Evaluation of potentiality, prospect and challenges of Bangladeshi shipbuilding in the light of global contest”, M.Sc. Engg. Thesis, submitted to Dept. of Naval Architecture and Marine Engineering, BUET, Dhaka, Bangladesh.
[14] Shahabullah, M., 2009, “Shipbuilding Industry of Bangladesh and its Export Possibility, EPB of Bangladesh”, The Daily Ittefaq \& The Daily Star, 01 January and www.shipbuildinghistory.com

[15] Huge, E.C.and Alan, D. A., 1988, “ The Spirit of Management Excellence”, Dow Jones Irwin

[16] Dave, U., 1997, "Human Resource Champions", Boston: Harvard Business School Press.

[17] Levin, R. I., David S. R. and Joel, P. S., 1986, "Quantitative Approaches to Management", New York:McGraw Hill.

[18] Banks, J., 1989, "Principles of Quality Control ”, New York: Wiley.

[19] Juran, J. M. and Frank, M. G., 1980, “ Quality Planning and Analysis”, New York: McGraw Hill.

[20] Zakaria, N.M.G., Hossain, K.A., 2010, “Service providers and supporting industries of shipbuilding sector in Bangladesh and its impact on overall development”, $13^{\text {th }}$ Annual Paper Meet, Mechanical Engineering Division, IEB, Paper no. MED-38, September 25, Dhaka.

[21] Mid-Term Review of the FFYP, 2009, Planning Commission, Ministry of Planning, Government of Peoples Republic of Bangladesh.

[22] Zakaria, N.M.G., Hossain, K.A. and Islam, M.S., 2010, "SWOT analysis of shipbuilding industries in Bangladesh and its challenges to become major shipbuilding nation", Journal of Ship Technology, India, Volume 6, No. 2, pp.45-57. 